\title{
The Portuguese Perspective
}

\author{
JOSÉ MANUEL PEDREIRINHO \\ Universidade Lusíada, Portugal \\ MICHEL TOUSSAINT \\ Universidade Lusiada, Portugal \\ PANCHO GUEDES \\ Universidade Lusíada, Portugal
}

José Manuel Pedreirinho was born and educated in Lisbon, and has operated his own practice there since 1984. In addition to teaching the history of modern architecture and the theory of architecture at the universities of Lisbon, Coimbra, and Porto, Prof. Pedreirinho is also completing a $P h D$ at the University of Bath (UK). The author of several articles and two books on Portuguese architecture and the teaching process, Prof. Pedreirinho is currently preparing a guide on the architecture of Porto.

Michel Toussaint is an architect and educator in Lisbon, where he teaches the theory of architecture at the Universidade Técnica de Lisboa and the Universidade Lusiada. Prof. Toussaint has published several essays, articles, and books on architectural topics, and has practiced in Portugal, Angola, and Macau.

Pancho Guedes is an architect currently working in Lisbon after an extensive career in Mozambique and South Africa. A graduate of the University of Witwatersrand (South Africa), Prof. Guedes' work is noted for it sculptural and expressionistic quality, influenced heavily by African art and the work of Gaudi. In addition to his academic career in Lisbon, Prof. Guedes has also taught at the Architectural Association in London.

[Editor's note: The text of these presentations was not available at the time of publication.] 